\title{
Comparison between Isothermal and Non-Isothermal Fatigue Behavior in a Cast Aluminum-Silicon-Magnesium Alloy
}

\author{
M. Azadi, ${ }^{a, 1}$ G. Winter, ${ }^{\text {b }}$ G. H. Farrahi, ${ }^{c}$ and W. Eichlseder ${ }^{\mathrm{b}}$ \\ ${ }^{a}$ Faculty of Mechanical Engineering, Semnan University, Semnan, Iran \\ ${ }^{b}$ Faculty of Mechanical Engineering, University of Leoben, Leoben, Austria \\ c School of Mechanical Engineering, Sharif University of Technology, Tehran, Iran \\ ${ }^{1}$ m.azadi.1983@gmail.com
}

УДК 539.4

\section{Сравнительный анализ изотермического и неизотермического усталостных процессов в литом алюмосиликатомагниевом сплаве}

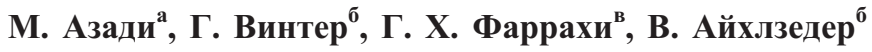 \\ a Университет г. Семнан, Иран \\ ${ }^{6}$ Университет г. Леобен, Австрия \\ в Технологический университет “Шариф”, Тегеран, Иран
}

Для литого алюмосиликатомагниевого сплава А356.0, иироко используемого для изготовления головок цилиндров дизельных двигателей, выполнен сравнительный анализ усталостных процессов при антифазном термомеханическом нагружении, а также при малоиикловом нагружении при комнатной и повыменной температурах. Проведены изотермические и неизотермические ииклические испытания с контролем деформаций и температуры, моделирующие эксплуатационные режимы нагружения головок ичилиндров. Результаты усталостных испытаний показывают, что пластическая деформаџия увеличивается при цииклческой наработке с постоянной амплитудой механической деформации до момента разрушения образцุов. При малочиикловом нагружении сплав характеризуется ичиклическим упрочнением при комнатной температуре и разупрочнением при высоких температурах, аналогичная тенденция наблюдается при антифазном термомеханическом нагружении. Радиальные и продольные температурные градиенты при антифазном термомеханическом нагружении составляют 2 и $3^{\circ} \mathrm{C}$ соответственно. Сравнение петель гистерезиса напряжение-деформация показывает, что растягивающие напряжения при минимальных температурах в условиях антифазного термомеханического нагружения (вследствие антифазных условий нагружения) были выле, чем при малочикловом нагружении. При этом максимальные температуры наблюдаются при сжатии, минимальные - при растяжении. Циклическая долговечность при антифазном термомеханическом нагружении вследствие более напряженных условий эксплуатации и изменений температуры ниже, чем при малоцикловом нагружении.

Ключевые слова: литой алюминиевый сплав, изотермическая и неизотермическая усталость, малоцикловая усталость, термомеханическая усталость, петля гистерезиса, циклическое упрочнение и разупрочнение.

Introduction. Nowadays, cast aluminum-silicon-magnesium alloys, such as A356.0 (AlSi7Mg0.3), have been widely used in diesel engine cylinder heads due to their relatively high strength to weight ratio, low cost, and providing affordable improvements in the fuel efficiency. As it is known, thermal and mechanical cyclic loadings were applied on cylinder heads during start-stop operations, and therefore, the non-isothermal fatigue behavior is 
become a major concern of automotive industries with regard to the component integrity and its reliability [1-3].

Many researchers have been worked on isothermal and non-isothermal fatigue behaviors of aluminum alloys. Most of them investigated high cycle fatigue (HCF) [4-13] and low cycle fatigue (LCF) [14-16] at both low and high temperatures. However, studies on the thermomechanical fatigue (TMF) behavior are still rare and researches have been continued.

At present, microstructure modeling for high-temperature cyclic behavior of the A319-T6 alloy was performed by Sehitoglu et al. [17, 18]. Beck et al. [19] performed TMF tests on two aluminum alloys (AlSi10Mg0.3 and AlSi10Mg0.6), un-reinforced and reinforced with $15 \%$ discontinuous $\mathrm{Al}_{2} \mathrm{O}_{3}$ (Saffil) fibers. Luft et al. [20] and Beck et al. [21] described TMF and superimposed TMF/HCF behaviors of the AlSi7Mg0.3 cast alloy. By metallographic investigations and scanning electron microscopy studies, they found that the crack initiation generally took place at the interface between eutectic silicon particles and the $\alpha$-Al matrix. In another research, Beck et al. [22] studied the out-of-phase TMF material behavior with superimposed HCF loadings on the AlSi6Cu4 alloy. Their results showed that at the maximum temperature of $300^{\circ} \mathrm{C}$, the lifetime for pure $\mathrm{TMF}$ loading was about 2000 cycles for $180 \mathrm{~s}$ and 3000 cycles for tests without dwell time and for lower maximum temperature $\left(250^{\circ} \mathrm{C}\right)$, this difference was become almost twice. Thomas et al. $[23,24]$ presented fatigue lifetime prediction models based on energy and classical approaches such as Smith-Watson-Topper (SWT) theory for the A356.0 alloy under TMF and LCF (at different temperatures) conditions.

The effect of different casting processes on isothermal (at low and high temperatures) and non-isothermal fatigue behaviors of aluminum-silicon alloys was studied by BoseFilho et al. [25]. Riedler et al. [26, 27] presented a special modified energy method, "unified energy approach" and compared to conventional approaches for the AlSi7MgCu0.5 alloy by using TMF tests results. Takahashi and Sasaki [28] checked the effect of artificial ageing on the TMF lifetime of the A356.0-T6 alloy. They found that the ageing time was so effective for the loop-end stress amplitude change rate. The change rate could be expressed as a state of the stress relaxation and there was a significant correlation (a reverse relation) between the change rate and the fatigue lifetime. Grieb et al. [29] performed TMF tests on cast aluminum alloys by using near-component-similar samples (such a valve bridge in cylinder heads) and derived an ageing model from experimental results.

Azadi et al. [30] presented a failure analysis on a gasoline engine cylinder head, made of aluminum alloy. Their results showed that there were many casting pores due to poor quality of casting in the failed cylinder head, which had certainly played a crucial role in initiating the crack. In another article, Azadi and Shirazabad [31] investigated the heat treatment effect on the A356.0 alloy under out-of-phase thermomechanical fatigue and low cycle fatigue (at different temperatures) loadings. Experimental fatigue results showed that the heat treatment process had a considerable influence on mechanical and low cycle fatigue behaviors, especially at low temperatures. However, its effect on thermomechanical fatigue lifetime was not significant. Azadi [32] presented effects of the strain rate and the mean strain on the cyclic behavior and the lifetime of aluminum-silicon alloys. He found that the strain ratio effect on high-temperature LCF behavior of the A357.0 alloy was more significant than that of the A356 alloy. He illustrated that increasing the strain rate increased the high-temperature LCF lifetime in the A357 alloy. No change could be observed in the out-of-phase TMF lifetime when the strain ratio increased. Azadi et al. [33] studied the effect of various parameters on out-of-phase TMF lifetime of the A356.0 cast aluminum alloy. Scanning electron microscopy images revealed that the A356.0 alloy had a ductile behavior. The cyclic softening phenomenon was also observed during stress-strain hysteresis loops. TMF tests results demonstrated that the dwell time had no significant effect upon the lifetime. 
Farrahi et al. [34] proposed a novel fatigue lifetime prediction model for the A356.0 alloy. This model was based on the plastic strain energy density per cycle including two correction factors, in order to consider the effect of the mean stress and the maximum temperature. In another article, Farrahi et al. [35] simulated a cylinder head, made from the A356.0 alloy, by the finite element method to obtain elasto-visco-plastic stresses. Farrahi et al. [36] presented numerical simulations of cyclic behaviors in light alloys under isothermal and thermomechanical fatigue loadings. For this purpose, an aluminum alloy (A356) a magnesium alloy (AZ91) were considered to study their stress-strain hysteresis loops by using two plasticity approaches including the Chaboche hardening model and the Nagode spring-slider model. Their results demonstrated a good agreement with experimental data at the mid-life cycle of fatigue tests. Tabibian et al. [37, 38] investigated lost foam casting) process affects on the microstructure, mechanical properties, damage mechanisms and the fatigue failure of aluminum alloys (A356.0 and A319.0). Besides, they observed a good agreement between predicted fatigue lifetimes and experimental results, obtained from different TMF and LCF loading conditions. Charkaluk et al. [39] proposed a novel method to establish and identify a probability density function, characterizing the fatigue lifetime. The method was initiated with a quantitative analysis of the microstructure of aluminum alloys. They showed that estimated lifetimes using the novel technique had a good agreement with experimental data.

In the present article, high-temperature fatigue behaviors of the A356.0 aluminum alloy have been investigated. According to this objective, TMF and LCF tests were conducted under various conditions (different temperatures and strain amplitudes). Isothermal and non-isothermal fatigue test results have been presented in figures to compare LCF and TMF behaviors of the material.

1. Materials and Experiments. The considered material in this research is a cast aluminum-silicon-magnesium alloy, entitled as A356.0 (AlSi7Mg0.3), which has been utilized in diesel engine cylinder heads. The element composition was measured as $7.06 \% \mathrm{Si}$, $0.37 \% \mathrm{Mg}, 0.15 \% \mathrm{Fe}, 0.01 \% \mathrm{Cu}, 0.02 \% \mathrm{Mn}, 0.13 \% \mathrm{Ti}$ and $\mathrm{Al}$ was remainder. The production process of this alloy was performed in permanent molds by the gravity casting method.

Strain/temperature-controlled isothermal and non-isothermal fatigue tests were conducted including out-of- phase TMF, room-temperature LCF and high-temperature LCF tests under various conditions. Related equipments of testing can be seen in Figs. 1 and 2. The strain was measured by a high-temperature extensometer during cycles. The temperature was measured by K-type thermocouples. The induction system was used for heating the specimen and the compressed air jet was used for cooling the specimen.

It is noteworthy that, in LCF tests, the temperature was constant during cycles, within a variation interval of $\pm 2^{\circ} \mathrm{C}$. Since LCF tests had isothermal conditions, based on ASTM-E606 standard (a standard practice for strain-controlled fatigue testing, 1992). However, in TMF tests, besides the mechanical strain, the temperature changed between the minimum value and maximum values, based on COP-EUR22281EN standard (a validated code-of-practice for strain-controlled thermomechanical fatigue testing, 2006). The strain rate was $60 \% / \mathrm{min}$ in LCF tests. In TMF tests, heating/cooling rate was constant as $10^{\circ} \mathrm{C} / \mathrm{s}$. As an initial condition, tests began with $0.03 \%$ of the mechanical strain, compared to initial cylinder head loadings. This load is comparable to initial bolts forces and valve seat insert effects. Thus, the strain ratio (the ratio of minimum to maximum strains), was almost equal to minus infinity. TMF tests started at a minimum temperature, which was constant as $50^{\circ} \mathrm{C}$. However, maximum temperatures were variable in tests (constant in a test) as 200 and $250^{\circ} \mathrm{C}$, according to operation conditions of cylinder heads. The constraint factor (or the thermomechanical loading factor) has been defined as the ratio of the mechanical strain amplitude to the thermal strain amplitude, which was considered as the thermal expansion coefficient multiplied to the temperature range. This constraint factor was constant during a TMF test and applied as $125 \%$ for all tests. 

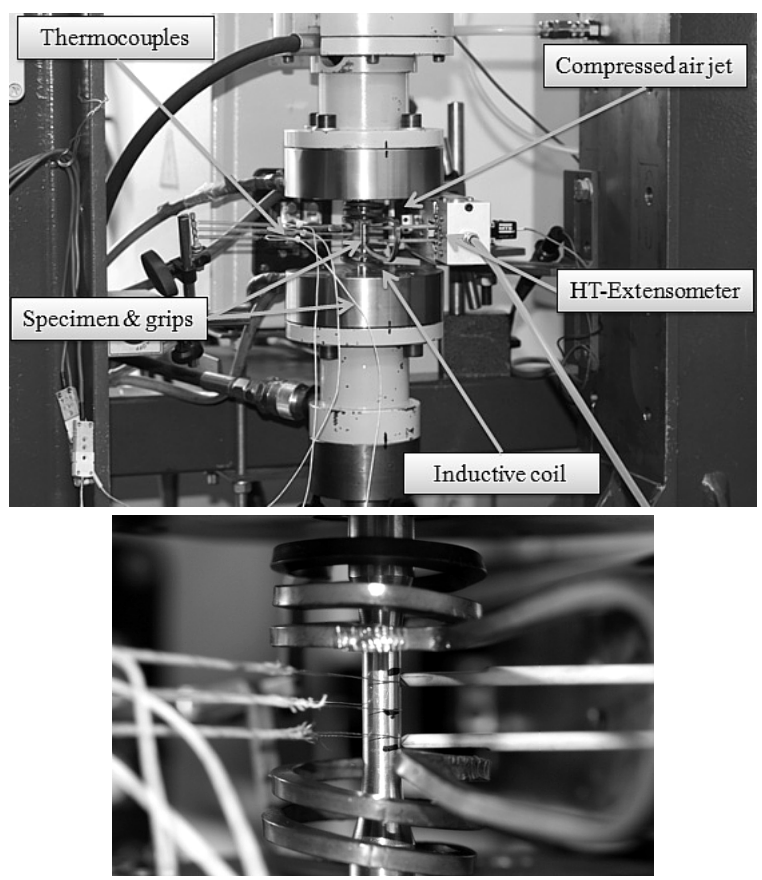

Fig. 1. TMF equipments with related accessories including induction heating and air jet cooling systems.
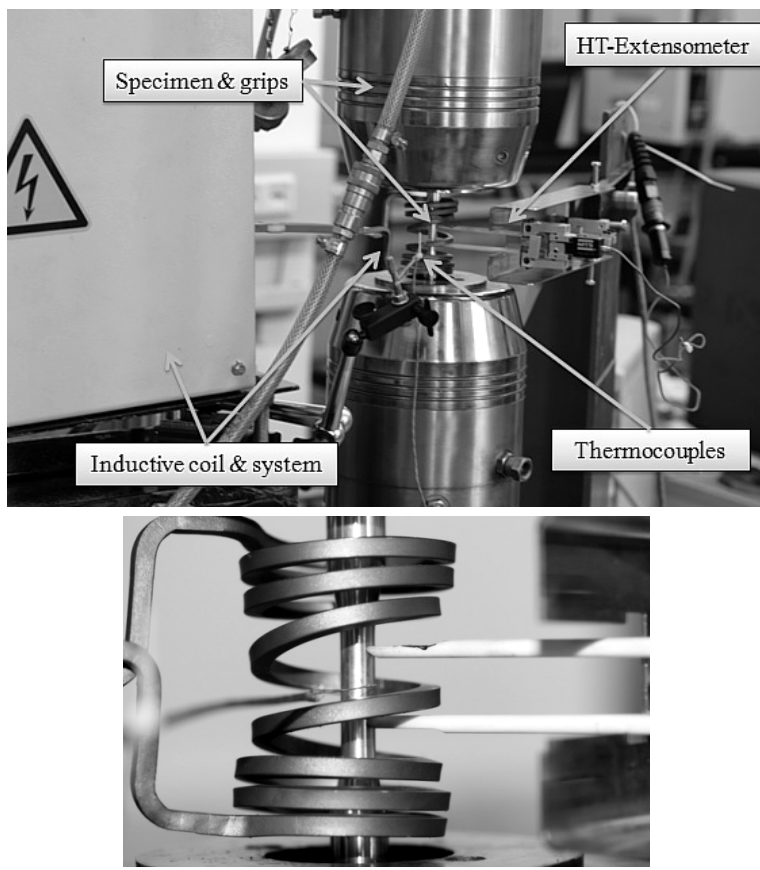

Fig. 2. LCF equipments with related accessories including induction heating system.

In the case of out-of-phase loading conditions, when the temperature reached its maximum value, the mechanical strain had the maximum compressive values and vice versa, which has been comparable to real conditions in cylinder heads. The out-of-phase loading condition during a TMF test (considering $225^{\circ} \mathrm{C}$ for the maximum temperature, 

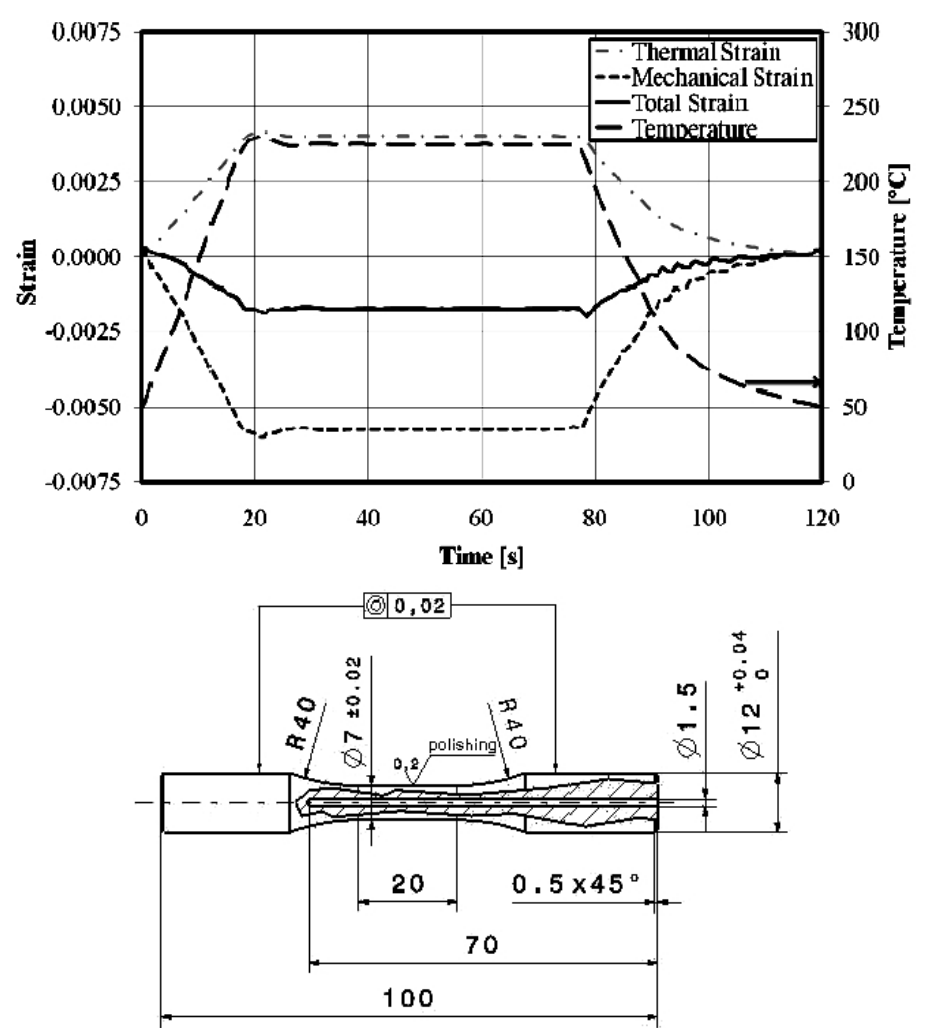

Fig. 3. Loading conditions during a TMF test and specimen geometry and dimensions in $\mathrm{mm}$.

$150 \%$ for the strain constraint and $60 \mathrm{~s}$ for the dwell time), as well as the geometry of used specimens are shown in Fig. 3. As it can be seen, an axial hole with $1.5 \mathrm{~mm}$ diameter in the middle of specimens was drilled to measure and control the temperature by the thermocouple.

Before each LCF test, the elastic modulus of the material was measured to check the obtained value with references. Before each TMF test, a zero-force test was performed to find the thermal strain of the material at different temperatures. In this case, firstly, the heating/cooling rate was considered as $2^{\circ} \mathrm{C} / \mathrm{s}$ under a zero mechanical stress level (including one cycle). The allowable value for stresses is less than $4 \mathrm{MPa}$ due to COP-EUR22281EN standard. This low heating/cooling rate was due to the absence of transient temperature behavior and to find the thermal expansion coefficient of the material. Then, the test was repeated at $10^{\circ} \mathrm{C} / \mathrm{s}$ (including one cycle) to find the real material behavior and measure the correction factor for the thermal strain. This process, which was temperature-based, is shown in Fig. 4, including the thermal strain, the correction factor and stress values during the zero-force test. As it can be seen, the stress was less than $2 \mathrm{MPa}$, which showed an agreement with the standard.

In brief, the configuration of out-of-phase TMF tests is listed as follows:

(i) initial strain: $0.03 \%$;

(ii) start temperature: $50^{\circ} \mathrm{C}$;

(iii) minimum temperature: $50^{\circ} \mathrm{C}$;

(iv) maximum temperature: 200 and $250^{\circ} \mathrm{C}$;

(v) constraint factor: $125 \%$;

(vi) dwell time (at the maximum temperature): $5 \mathrm{~s}$;

(vii) heating/cooling rate: $10^{\circ} \mathrm{C} / \mathrm{s}$. 

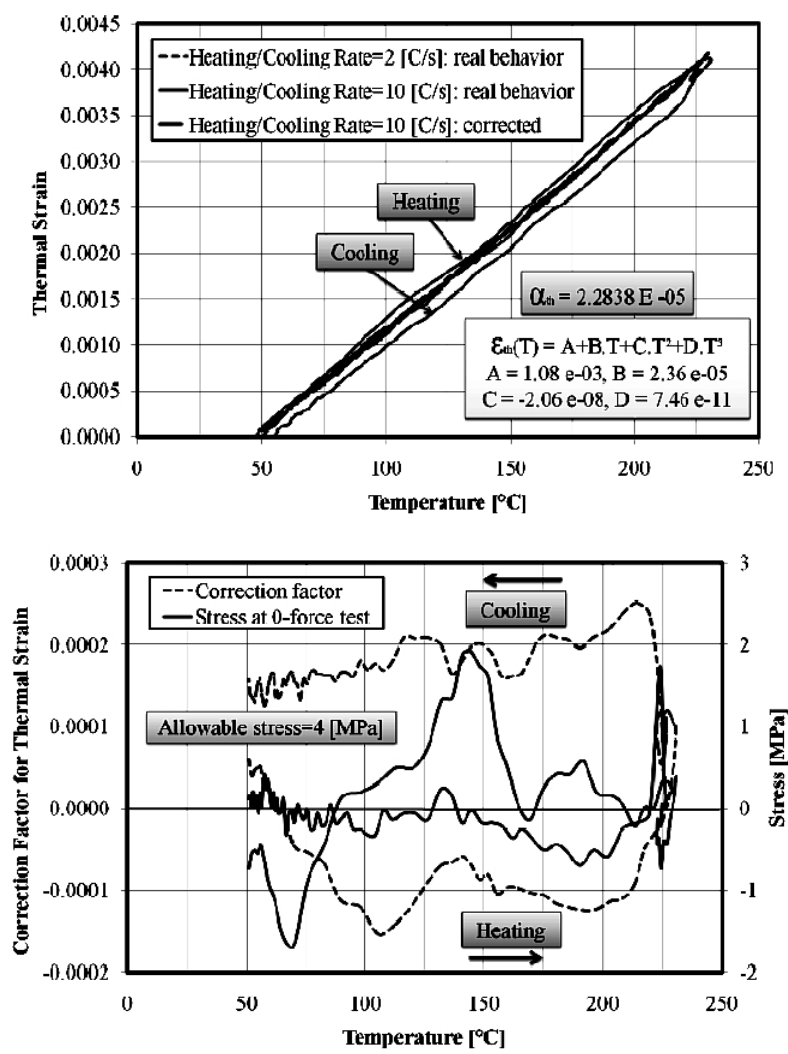

Fig. 4. Thermal expansion coefficient, thermal strain and its correction factor measurement in TMF tests.

Meanwhile, the configuration of room-temperature and high-temperature LCF tests was as follows:

(i) temperature: 25,200 , and $250^{\circ} \mathrm{C}$;

(ii) strain rate: $60 \% / \mathrm{min}$;

(iii) strain amplitude: 0.20 and $0.30 \%$ (measured from the mid-life cycle of TMF tests results);

(iv) strain ratio: -12.3 and -19.0 (measured from the mid-life cycle of TMF tests results)

2. Results and Discussion. In TMF tests, the temperature was controlled according to the demanded temperature. The difference between demanded and real temperatures was measured as $4.7^{\circ} \mathrm{C}$ at the maximum temperature. This temperature difference should be less than $5^{\circ} \mathrm{C}$ according to COP-EUR22281EN standard. The longitudinal temperature gradient within $12 \mathrm{~mm}$ of the gauge length was almost $3^{\circ} \mathrm{C}$ and the radial temperature gradient was $2^{\circ} \mathrm{C}$. These temperature gradients are shown in Fig. 5 . These gradients were also in a good agreement with the standard.

Before analyzing the results obtained for hysteresis loops at different cycles, it should be noted that the specimen failure was defined as the first drop in the history of the maximum stress versus the time. This definition shows the fatigue lifetime of the specimen. Stress-strain and stress-temperature hysteresis loops at different cycles are shown in Fig. 6 for a TMF test. In this experiment, the maximum temperature was $225^{\circ} \mathrm{C}$. The enhancement of the plastic strain could be observed during cycles and therefore, the cyclic softening behavior occurred in the A356.0 alloy. According to [40-42], if the ultimate tensile strength 

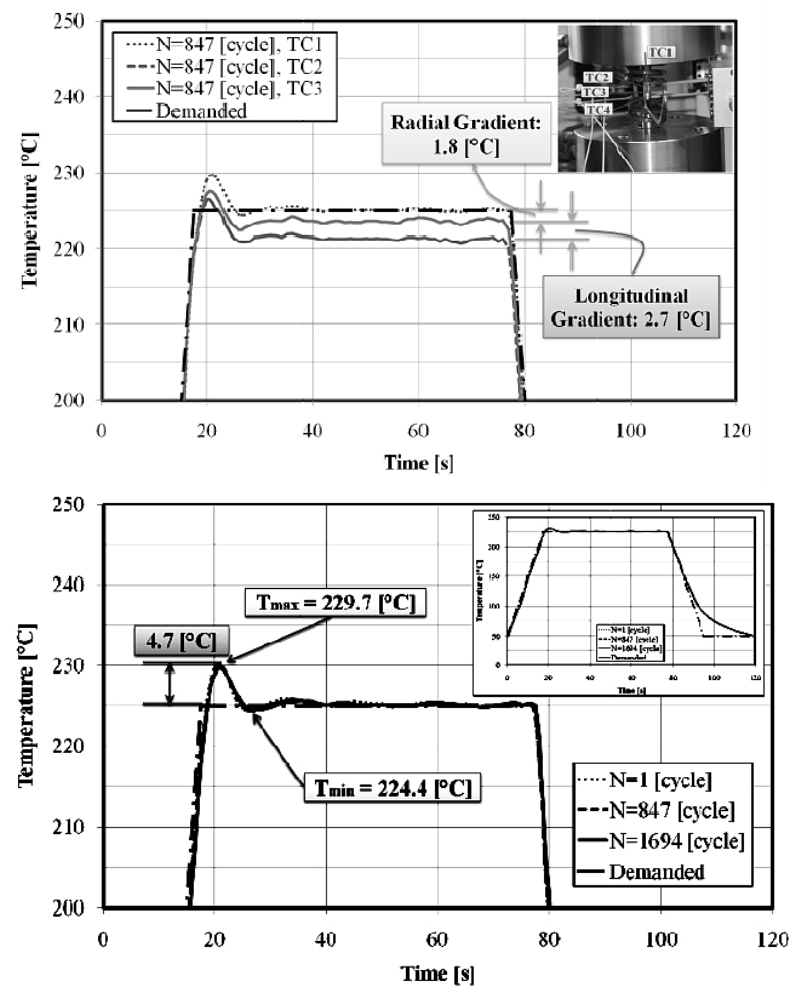

Fig. 5. Radial and axial temperature gradients during a TMF test with a dwell time.
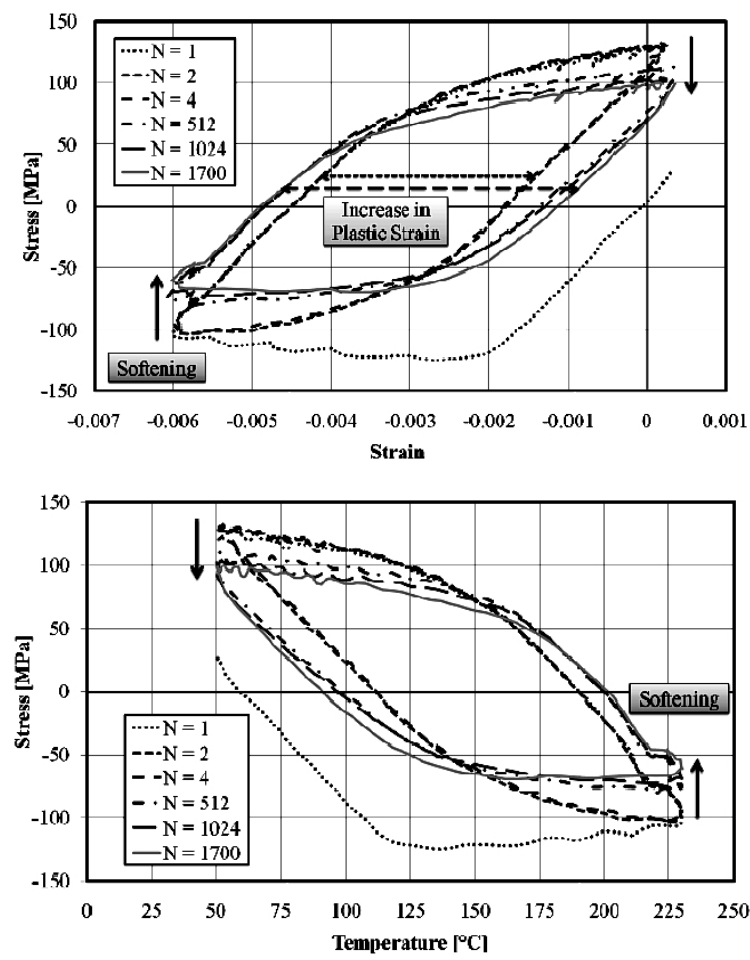

Fig. 6. Stress-strain and stress-temperature hysteresis loops for different cycles in TMF tests. 
to the $0.2 \%$ offset yield strength is greater than 1.4 , the cyclic hardening behavior will occur and if this ratio is smaller than 1.2, the cyclic softening behavior will occur in the material. It is noteworthy that the ratio of ultimate stresses to yield ones was measured as 1.1 for the A356.0 alloy according to tensile tests at high temperatures (between 150 to $250^{\circ} \mathrm{C}$ ). Hysteresis loops for room-temperature and high-temperature LCF tests are shown in Fig. 7. Obtained results demonstrated that the cyclic hardening behavior at the room temperature and the cyclic softening behavior at high temperatures $\left(250^{\circ} \mathrm{C}\right)$ for the $\mathrm{A} 356.0$ aluminum-silicon-magnesium alloy. In the case of the cyclic hardening behavior, the stress increased and the plastic strain decreased during cycles. However, in the case of the cyclic softening behavior, the stress decreased and the plastic strain increased during cycling.
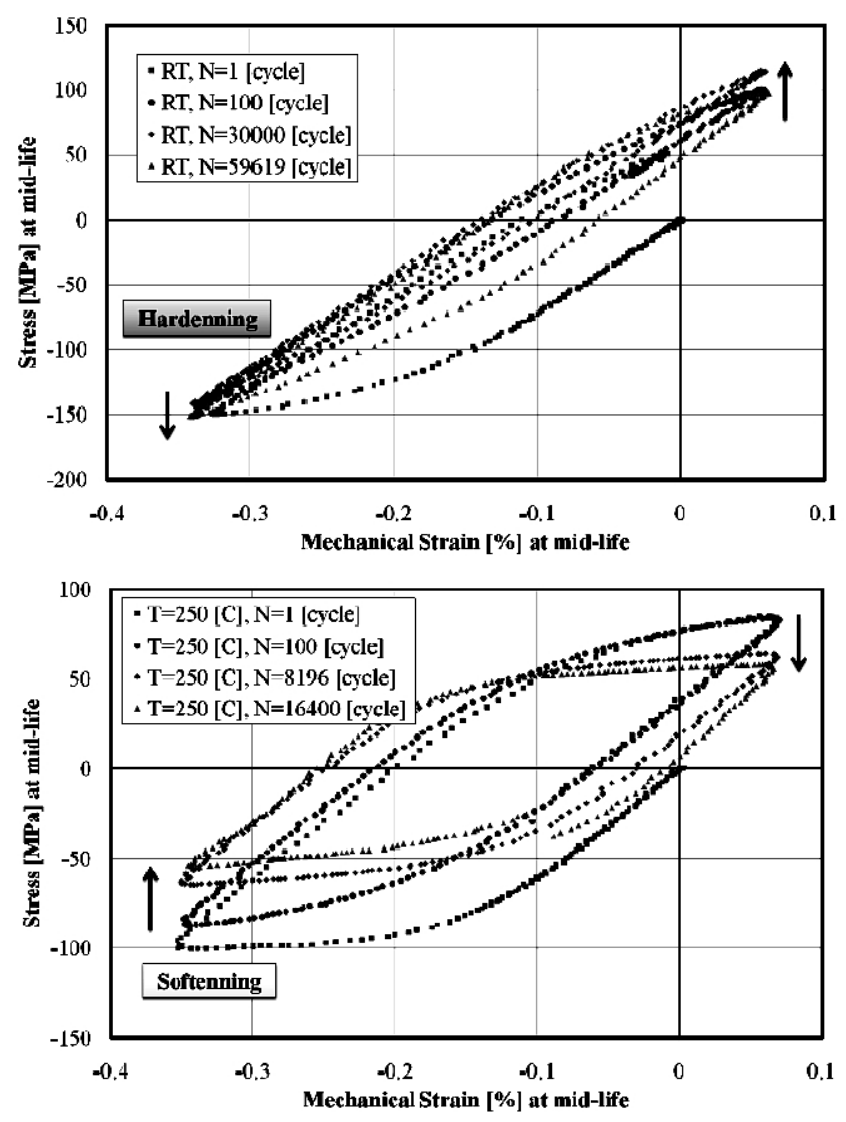

Fig. 7. Stress-strain hysteresis loops for different cycles in LCF tests at room temperature and $250^{\circ} \mathrm{C}$.

The maximum and minimum stresses, the stress amplitude and the mean stress are depicted in Fig. 8 for both TMF and high-temperature LCF tests versus the fatigue lifetime (in a logarithmic scale). In addition, the total mechanical strain and the plastic strain versus the fatigue lifetime (in a logarithmic scale) and also stress-strain hysteresis loops are shown in Fig. 9. It should be mentioned that plastic strain was calculated by the fatness of the hysteresis loop, where the mean stress was zero. Then, the elastic part was calculated as the difference between the total mechanical strain and the plastic strain.

Figures 8 and 9 (including stress and strain histories) show the cyclic softening behavior of the A356.0 alloy under TMF and high-temperature LCF loadings, as also illustrated in Figs. 6 and 7. Moreover, the maximum stress at TMF tests was more than that one at high-temperature LCF tests. The reason was due to the time when the minimum 

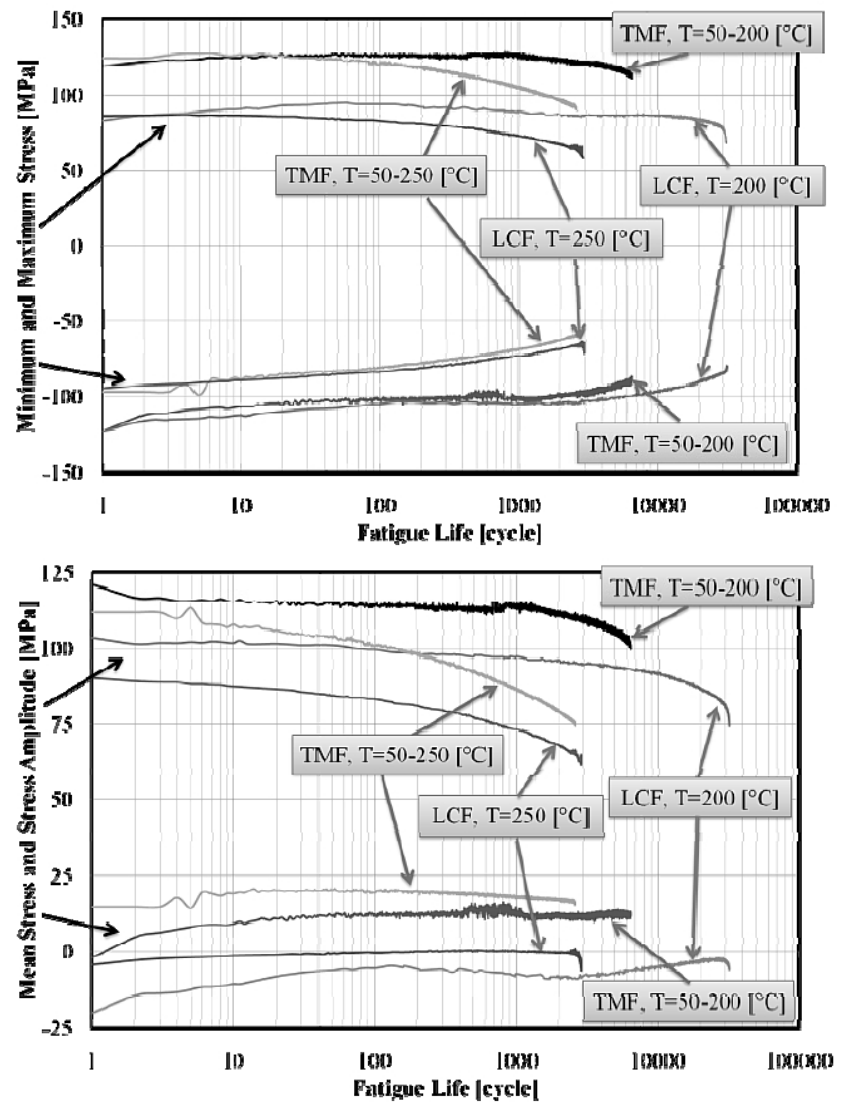

Fig. 8. The maximum and minimum stresses, mean stress, and stress amplitude in TMF/LCF tests.

temperature occurred at the tensile stress under the out-of-phase loading condition. At the minimum temperature, the stress had almost the same value in both TMF and LCF tests (Fig. 9). Although in LCF tests, the temperature was constant according to isothermal conditions, but the LCF lifetime was higher than the TMF one. This was due to have transient temperatures and severe conditions in non-isothermal TMF tests in comparison to isothermal LCF tests. It should be mentioned that we attempted to compare TMF and LCF behaviors of the A356.0 alloy for the same value of the mechanical strain. However, small differences existed in results of the total mechanical strain amplitude, which could be negligible for comparing TMF and LCF lives. In the LCF test at $250^{\circ} \mathrm{C}$, the strain amplitude was somewhat higher, but the lifetime also exceeded the TMF one. The plastic strain in this case was higher in the LCF test, in comparison to that in the TMF test, but at lower temperatures $\left(200^{\circ} \mathrm{C}\right)$, the respective plastic strains were almost identical.

Conclusions. High-temperature fatigue behaviors of the A356.0 alloy has been studied by considering different test types including TMF and LCF conditions. Isothermal fatigue test results showed that the cyclic softening behavior occurred for the A356.0 alloy at high temperatures and the cyclic hardening behavior occurred at the room temperature. Besides, for non-isothermal fatigue tests, the cyclic softening behavior occurred for the A356.0 alloy. In addition, the TMF lifetime was less than the high-temperature LCF lifetime at the same condition for the A356.0 alloy. This is attributed to severe non-isothermal loadings conditions (transient temperatures) in TMF tests.

Acknowledgments. Authors thank Irankhodro Powertrain Company (IPCO) in Iran and University of Leoben in Austria, for their financial support. 

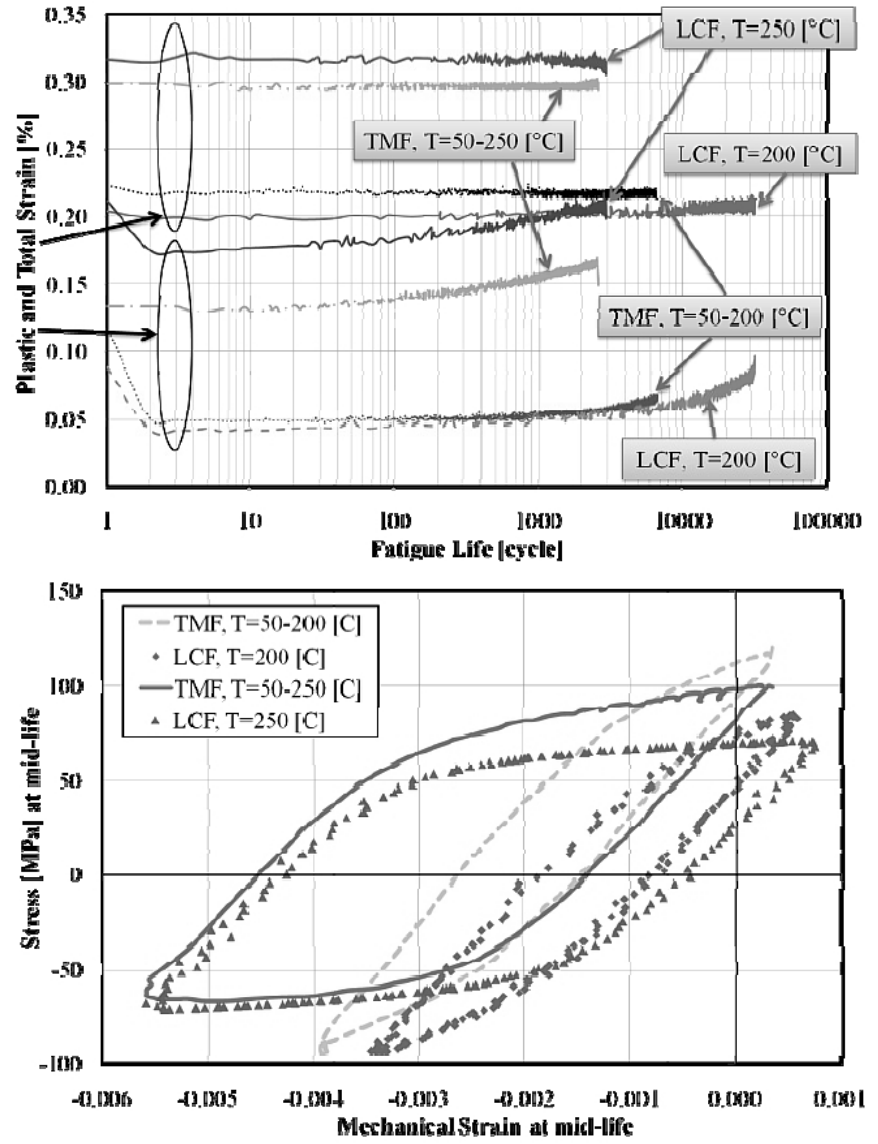

Fig. 9. Total and plastic strains and stress-strain hysteresis loop in TMF/LCF tests.

\section{Резюме}

Для литого алюмосилікатомагнієвого сплаву А356.0, що широко використовується для виготовлення головок циліндрів дизельних двигунів, виконано порівняльний аналіз втомних процесів при антифазному термомеханічному навантаженні та при малоцикловому навантаженні за кімнатної і підвищеної температур. Проведено ізотермічні і неізотермічні циклічні випробування з контролем деформацій і температури, що моделюють експлуатаційні режими навантаження головок циліндрів. Результати втомних випробувань показують, що пластична деформація збільшується при циклічному напрацюванні з постійною амплітудою механічної деформації до моменту руйнування зразків. При малоцикловому навантаженні сплав характеризується циклічним зміцненням за кімнатної температури й знеміцненням при високих температурах, аналогічна тенденція спостерігається при антифазному термомеханічному навантаженні. Радіальні і поздовжні температурні градієнти при антифазному термомеханічному навантаженні становлять 2 і $3^{\circ} \mathrm{C}$ відповідно. Порівняння петель гістерезису напруженнядеформація показує, що розтяжні напруження при мінімальних температурах в умовах антифазного термомеханічного навантаження (внаслідок антифазних умов навантаження) були вищими, ніж при малоцикловому навантаженні. При цьому максимальні температури відмічаються при стиску, мінімальні - при розтязі. Циклічна довговічність при антифазному термомеханічному навантаженні внаслідок більш напружених умов експлуатації та змін температури нижча, ніж при малоцикловому навантаженні. 
1. J. Z. Yi, P. D. Lee, T. C. Lindley, and T. Fukui, "Statistical modeling of microstructure and defect population effects on the fatigue performance of cast A356-T6 automotive components," Mater. Sci. Eng. A, 432, 59-68 (2006).

2. A. Moridi, M. Azadi, and G. H. Farrahi, "Coating thickness and roughness effect on stress distribution of A356.0 under thermo-mechanical loadings," Proc. Eng., 10, 1372-1377 (2011).

3. A. Moridi, M. Azadi, and G. H. Farrahi, "Thermo-mechanical stress analysis of thermal barrier coating system considering thickness and roughness effects," Surf. Coat. Technol., 243, 91-99 (2012).

4. D. L. McDowell, K. Gall, M. F. Horstemeyer, and J. Fan, "Microstructure-based fatigue modeling of cast A356-T6 alloy," Eng. Fract. Mech., 70, 49-80 (2003).

5. B. Atzori, G. Meneghetti, and L. Susmel, "Fatigue behavior of AA356-T6 cast aluminum alloy weakened by cracks and notches," Eng. Fract. Mech., 71, 759-768 (2004).

6. X. Zhu, A. Shyam, J. W. Jones, et al., "Effects of microstructure and temperature on fatigue behavior of E319-T7 cast aluminum alloy in very long life cycles," Int. J. Fatigue, 28, 1566-1571 (2006).

7. Y. X. Gan and R. A. Overfelt, "Fatigue property of semisolid A357 aluminum alloy under different heat treatment conditions," J. Mater. Sci., 41, 7537-7544 (2006).

8. J. Z. Yi, Y. X. Gao, P. D. Lee, and T. C. Lindley, "Microstructure-cased fatigue life prediction for cast A356-T6 aluminum-silicon alloys," Metall. Mater. Trans. B, 37, 301-311 (2006).

9. D. L. McDowell, "Simulation-based strategies for microstructure-sensitive fatigue modeling," Mater. Sci. Eng. A, 468-470, 4-14 (2007).

10. H. R. Ammara, A. M. Samuela, and F. H. Samuel, "Porosity and the fatigue behavior of hypoeutectic and hypereutectic aluminum-silicon casting alloys," Int. J. Fatigue, 30, 1024-1035 (2008).

11. M. A. Bayoumi, M. I. Negma, and A. M. El-Gohry, "Microstructure and mechanical properties of extruded Al-Si alloy (A356) in the semi-solid state," Mater. Des., 30, 4469-4477 (2009).

12. J. J. I. Mattos, A. Y. Uehara, M. Sato, and I. Ferreira, "Fatigue properties and micro-mechanism of fracture of an $\mathrm{AlSiMg} 0.6$ cast alloy used in diesel engine cylinder head," Proc. Eng., 2, 759-765 (2010).

13. P. K. Rohatgi, S. Alaraj, R. B. Thakkar, and A. Daoud, "Variation in fatigue properties of cast A359-SiC composites under total strain controlled conditions: effects of porosity and inclusions," Compos. Part A, 38, 1829-1841 (2007).

14. A. R. Emami, S. Begum, D. L. Chen, et al., "Cyclic deformation behavior of a cast aluminum alloy," Mater. Sci. Eng. A, 516, 31-41 (2009).

15. S. Mousheng and R. Maowu, "Microstructures and properties of low cycle fatigue of electrolytic A356 alloys," Mater. Charact., 62, 367-372 (2011).

16. T. Takahashi, Y. Sugimura, and K. Sasaki, "Thermal plastic-elastic analysis in consideration of metallurgical microstructure," J. Manuf. Sci. Eng., 126, 25-32 (2004).

17. T. J. Smith, H. J. Maier, H. Sehitoglu, et al., "Modeling high-temperature stress-strain behavior of cast aluminum alloys," Metall. Mater. Trans. A, 30, 133-146 (1999).

18. H. Sehitoglu, X. Qing, T. Smith, et al., "Stress-strain response of a cast 319-T6 aluminum under thermo-mechanical loading," Metall. Mater. Trans. A, 31, 139-151 (2000). 
19. T. Beck, K. H. Lang, and D. Löhe, "Thermal-mechanical fatigue behavior of cast aluminum alloys for cylinder heads reinforced with 15 vol.\% discontinuous $\mathrm{Al}_{2} \mathrm{O}_{3}$ (Saffil) fibers," Mater. Sci. Eng. A, 319-321, 662-666 (2001).

20. J. Luft, T. Beck, and D. Löhe, "Lifetime and damage behavior of a cast aluminum alloy under TMF and superimposed TMF/HCF loading," in: Proc. of the 11th Int. Conf. on Fracture (March 20-25, 2005, Turin), Politecnico di Torino, Turin, Italy (2005), Vol. 4, pp. 2664-2669.

21. T. Beck, D. Löhe, J. Luft, and I. Henne, "Damage mechanisms of cast Al-Si-Mg alloys under superimposed thermal-mechanical fatigue and high-cycle fatigue loading," Mater. Sci. Eng. A, 468-470, 184-192 (2007).

22. T. Beck, I. Henne, and D. Löhe, "Lifetime of cast AlSi6Cu4 under superimposed thermal-mechanical fatigue and high-cycle fatigue loading," Mater. Sci. Eng. A, 483-484, 382-386 (2008).

23. J. J. Thomas, L. Verger, A. Bignonnet, and S. M. Borret, "Thermo-mechanical design in the automotive industry," SAE Int., Paper No. 2002-01-0659 (2002).

24. J. J. Thomas, L. Verger, A. Bignonnet, and E. Charkaluk, "Thermo-mechanical design in the automotive industry," Fatigue Fract. Eng. Mater. Struct., 27, 887-895 (2004).

25. W. W. Bose-Filho, E. R. de Freitas, V. F. da Silva, et al., "Al-Si cast alloys under isothermal and thermo-mechanical fatigue conditions," Int. J. Fatigue, 29, 1846-1854 (2007).

26. M. Riedler, C. Czettl, R. Minichmayr, et al., "Thermo-mechanical fatigue lifetime assessment with damage-parameters, energy-criteria and cyclic-J-integral concepts," in: Proc. of the 16th Eur. Conf. on Fracture (July 3-7, 2006), Alexandroupolis, Greece (2006).

27. M. Riedler, H. Leitner, B. Prillhofer, et al., "Lifetime simulation of thermomechanically loaded components," Meccanica, 42, 47-59 (2007).

28. T. Takahashi and K. Sasaki, "Low cycle thermal fatigue of aluminum alloy cylinder head in consideration of changing metrology microstructure," Proc. Eng., 2, 767-776 (2010).

29. M. B. Grieb, H. J. Christ, and B. Plege, "Thermo-mechanical fatigue of cast aluminum alloys for cylinder head applications - experimental characterization and life prediction," Proc. Eng., 2, 1767-1776 (2010).

30. M. Azadi, A. Mafi, M. Roozban, and F. Moghaddam, "Failure analysis of a crack gasoline engine cylinder head," J. Fail. Anal. Prev., 12, No. 3, 286-294 (2012).

31. M. Azadi, M. M. Shirazabad, "Heat treatment effect on thermo-mechanical fatigue and low cycle fatigue behaviors of A356.0 aluminum alloy," Mater. Des., 45, 279-285 (2013).

32. M. Azadi, "Effects of strain rate and mean strain on cyclic behavior of aluminum alloys under isothermal and thermo-mechanical fatigue loadings," Int. J. Fatigue, 47, 148-153 (2013).

33. M. Azadi, G. H. Farrahi, G. Winter, and W. Eichlseder, "The effect of various parameters on out-of-phase thermo-mechanical fatigue lifetime of A356.0 cast aluminum alloy," Int. J. Eng. Trans. C: Aspects, 26, No. 12, 1461-1470 (2013).

34. G. H. Farrahi, M. Azadi, G. Winter, and W. Eichlseder, "A new energy-based isothermal and thermo-mechanical fatigue lifetime prediction model for aluminumsilicon-magnesium alloy," Fatigue Fract. Eng. Mater. Struct., 36, No. 12, 1323-1335 (2013). 
35. G. H. Farrahi, M. Ghodrati, and M. Azadi, "Finite element analysis of thermal and mechanical stresses in diesel engine cylinder head using two-layer elastic-viscoplastic model," J. Eng. Res., 28, 51-60 (2012).

36. G. H. Farrahi, A. Shamloo, M. Felfeli, and M. Azadi, "Numerical simulations of cyclic behaviors in light alloys under isothermal and thermo-mechanical fatigue loadings," Mater. Des., 56, 245-253 (2014).

37. S. Tabibian, E. Charkaluk, A. Constantinescu, et al., "TMF criteria for lost foam casting aluminum alloys," Fatigue Fract. Eng. Mater. Struct., 36, 349-360 (2013).

38. S. Tabibian, E. Charkaluk, A. Constantinescu, et al., "TMF-LCF life assessment of a lost foam casting A319 aluminum alloy," Int. J. Fatigue, 53, 75-81 (2013).

39. E. Charkaluk, A. Constantinescu, F. Szmytka, and S. Tabibian, "Probability density functions: from porosities to fatigue lifetime," Int. J. Fatigue, 63, 127-136 (2014).

40. A. F. Liu, Mechanics and Mechanisms of Fracture: An Introduction, ASM International (2005).

41. S. S. Manson and G. R. Halford, Fatigue and Durability of Structural Materials, ASM International (2006).

42. M. Azadi, G. H. Farrahi, G. Winter, and W. Eichlseder, "Thermo-mechanical behaviors of light alloys in comparison to high temperature isothermal behaviors," Mater. High Temp., 31, No. 1, 12-17 (2014). 